\title{
Independent Learning in the Covid-19 Pandemic
}

\author{
Susan Fitriasari ${ }^{1, *}$ Akhmad Fauzi ${ }^{2}$ \\ ${ }^{1,2}$ Universitas Pendidikan Indonesia, Bandung, Indonesia \\ ${ }^{*}$ Corresponding author. Email: susan fitriasari@upi.edu
}

\begin{abstract}
The COVID-19 pandemic demands that learning be carried out through online learning so that it requires educators to be more able to create spiritual nuances. Online learning requires educators to be as creative as possible to create a fun learning media so that online learning is not saturating. Online learning changes the habit of teachers as a center in teacher center learning to become a student center and requires students to be independent in learning. Online learning makes teachers unable to immediately see the development of students and requires both educators and students to be familiar with the technology. This correlates with the demands for teachers to be creative in managing virtual classrooms and requires students to adhere to the long-life learning principle that learning is anywhere, learning from anywhere, learning from anyone as long as knowledge is useful and good. Therefore, the development of independent learning is very important for students in the new normal today. Independent learning is very useful in order to foster intellectual intelligence (transfer of knowledge), but in the process of education or character building and maturity of students, the presence of teachers is still irreplaceable
\end{abstract}

Keywords: Creative, Media, Online Learning.

\section{INTRODUCTION}

The Independent learning is one of the important things in a learning process. Independent learning is needed for every teenager and students, so that they have the responsibility to organize and discipline themselves, in addition to being able to develop the ability to learn on their own accord [1]. These attitudes need to be owned by every student, because these attitudes are a hallmark of the maturity of an educated person. the demand for independence is very large and if it is not responded properly it can have an unfavorable impact on psychological development in the future [2]. This condition occurs because being independent is one of the main developmental tasks for adolescents. The demands of being independent in order to complete further developmental tasks are not easy for adolescents, to be independent requires opportunities, support and encouragement in order to achieve self-reliance.

Independent learning is a learning activity that takes place more driven by one's own abilities, own choices and self-responsibility in learning [3]. Adolescents are said to have been able to learn independently if they have been able to carry out learning tasks without dependence on others. Basically, independence is the behavior of individuals who are able to take the initiative, are able to overcome obstacles or problems, have self-confidence and can do things on their own without the help of others.
A phenomenon that often occurs among teenagers, both students and college students, is that they are not able to be independent in learning. This is due to some negative habits, such as studying only before exams, truancy, cheating, and looking for leaked exam questions. the existence of this phenomenon causes mental disorders that will continue when entering further education. Self-study independence is needed in the higher education system, because it will help individuals to learn actively [4].

Independent learning combined with student activity to support the learning process is very dependent on current conditions. The development of the times requires every individual to be able to develop following changes, one of the areas that has an impact is the field of education, especially technological developments are supported by the phenomenon that students are closer to smartphones than learning media such as textbooks or the like.

Seeing the learning process through online, this is in accordance with the learning principles contained in Permendikbud No 22 of 2016 concerning Process Standards, including learning that takes place at home, at school, and in the community; learning that applies the principle that anyone is a teacher, anyone is a student, and anywhere is a class; and the use of information and communication technology to improve the efficiency and effectiveness of learning. The problem that occurs today is the learning process that is forced to be done at home, 
since the pandemic that occurred in the world, including Indonesia.

The government's decision, especially the Ministry of Education and Culture regarding the teaching and learning process carried out online in the context of preventing the spread of COVID-19, is an alternative choice so that learning continues to run online. E-learning is a change in learning activities, which for students provides a different atmosphere than usual, thus avoiding the impression of being boring in the classroom by utilizing information technology and computers [5].

Independent learning is a learning activity carried out by individuals with their freedom without depending on the help of others as an increase in knowledge, skills, or achievement development, which include; determine and manage their own teaching materials, time, place, and utilize various learning resources needed. With this freedom, individuals have the ability to manage learning methods, have a high sense of responsibility, and are skilled at utilizing learning resources. Learning independence is also useful for individuals to be able to overcome a problem that is built with the knowledge or competencies they already have [6]. Meanwhile, the purpose of independent learning is not individual learning, but a learning process that demands the independence of a student to learn [7].

\subsection{The Structure of Independent Learning}

Independent learning is very important and needs to be developed in students as learners. If adjusted based on the definition of independence, when students are able to be independent in learning, students will try optimally to complete the exercises or tasks given by the teacher without depending on others, students will try to do it themselves according to their abilities. The importance of independence, that learning independence applied by students brings positive changes to intellectuality. Seeing the importance of independent learning for students, the development of learning skills is one aspect that must be developed [8].

Skill development is a process that will lead to productive activities for students. Judging from the current development of students, technology is not something that is difficult for them to understand, because it has become knowledge that they get selftaught. The skills of students in online learning can already be done by themselves, they can operate technology and even use the internet they often do for learning, one of which is that many students are currently using online learning applications such as Ruang Guru. Learning independence has characteristics that occur in each student which can be observed with changes in attitudes that arise through behavior patterns [9].

Characteristics of students who have independent learning include having responsibility, having confidence in their abilities and being able to make the best use of time to study. Based on the various opinions above, learning independence is indicated by the ability to be able to solve problems faced by behavior. With changes in behavior, children have an increase in thinking, learn to be independent without relying on help from others and are able to be responsible for being able to do homework (PR) without having to involve other people, such as having to be reminded by parents, done by parents, or see a friend's work. They will not be easily influenced by others regarding the learning process. They will try their best to solve their own problems without the help of others.

There are eight characteristics of independent learning, namely: 1) being able to think critically, creatively and innovatively; 2) not easily influenced by the opinions of others; 3 ) not running or avoiding trouble; 4) solve problems with deep thinking; 5) when you encounter a problem, you solve it yourself without asking for help from others; 6) don't feel inferior if you have to be different from other people; 7) trying to work with diligence and discipline; and 8) take responsibility for their own actions [10].

\section{THEORETICAL REVIEW}

Elements that influence the learning process to be effective are strategies in determining learning objectives, knowing when strategies are used and monitoring the effectiveness of these learning strategies. In the learning process at the elementary, middle, and advanced levels, self-regulated learning is an important approach [11]. The self-regulated learning strategy is suitable for all levels of education, except for the third grade of elementary school and below, some say that the self-regulated learning strategy is not suitable [12].

self-regulated learning as the degree to which students actively involve metacognition, motivation, and behavior in the learning process. Self-regulated learning is also defined as a form of individual learning depending on their learning motivation, autonomously developing and measuring (cognition, metacognition, and behavior), and monitoring their learning progress [13]

Selfregulated learning integrates many things about effective learning. Knowledge, motivation, and self-discipline or volition are important factors that can influence self- regulated learning [14]. Self-regulated learning consists of motivation and learning strategies. Motivation consists of: 1) Intrinsic goal orientation, 2) Extrinsic goal orientation, 3) Task values, 4) Control of learning beliefs, 5) Self-efficacy for learning and performance, and 6) Test anxiety. While learning strategies can be in the form of: 1) Rehearsal, 2) Elaboration, 3) Organization, 4) Critical thinking, 5) Metacognitive self-regulation, 6) Time and study environment, 7) Effort regulation, 8) Peer learning, and 9) Help seeking [15].

The steps in achieving self-regulation as follows: 1) Self-observation (self-monitoring), when observations are made will produce a perception of progress, it can motivate a person to improve his 
performance by changing what he has done. Before an individual changes his behavior, he must first be aware of his behavior. This involves monitoring or monitoring one's own behavior. The more systematically the individual monitors his behavior, the faster the individual becomes aware of what he is doing. 2) Self-evaluation (self-assessment), at this stage students determine whether the actions taken are as desired, namely in accordance with the individual's personal standards. Personal standards are derived from information that individuals obtain from others. Students compare a person's performance with a standard will provide information about the progress that has been achieved. By conducting a self-assessment, students can determine whether their actions are on the right track. 3) Selfreaction (maintaining internal motivation), at this stage students create encouragement for their own behavior, acknowledge and prove their competence, then feel satisfied with themselves so that they can increase interest in doing something [16].

Meanwhile, according to North Central Regional Educational Laboratory (NCRL), three metacognitive self-regulation strategies can be developed to achieve student learning success, namely: 1) The learning planning stage includes the process of estimating the time needed to complete learning tasks, planning study time in the form of a schedule and determining the priority scale in learning, organizing subject matter, taking appropriate steps to learn using various learning strategies (outlining, mind mapping). , speed reading, and strategies other learning). 2) The stage of the conscious learning process, including the process of setting learning goals, considering learning resources that will and can be accessed (for example: using textbooks, looking for source books in the library, accessing the internet in a computer lab, or studying in a quiet place), determining how to perform The best students will be evaluated, considering the level of learning motivation, determining the level of student learning difficulties. 3) The monitoring and learning reflection stages include the process of reflecting on the learning process, monitoring the learning process through questions and self-tests (self-testing, such as asking questions, is this material meaningful and useful to me? How can I master the knowledge of this material?, why? I find it easy/difficult to master this material?), maintain high concentration and motivation in learning.

Students who learn by self-regulation can be termed 'expert' students. Expert students know themselves and how they learn best. They know their preferred learning style, what is easy and difficult for them, how to overcome the difficult parts, what are their interests and talents, and how to take advantage of their strengths [17]. They also know the material they are studying; the more material they learn the more they know, and the easier it is to learn more [18]. They may understand that different learning tasks require different approaches. They also realize that learning is often difficult and knowledge is rarely absolute; there are usually many different ways of looking at the problem and many different solutions [19].

\section{METHODS}

This study uses descriptive quantitative research methods. Data collection was carried out from May 29, 2021 to July 13, 2020. The population in this study were all teenagers who had an age range of 15 to 21 years and they lived in Bandung. Sample selection using snowball sampling technique. The researcher contacted Guidance and Counseling teachers in several schools (SMA and SMK) to ask their students to be willing to be participants in the study. The teacher contacted one of the students, then the student asked a friend to be willing and continued. During this time, the total number of participants was 579 people.

Table 1 Profile of the Research Participants

\begin{tabular}{|l|c|c|}
\hline Category & Total & \% \\
\hline Gender & & \\
\hline Male & 258 & $45 \%$ \\
Female & 321 & $55 \%$ \\
\hline Type of Education & & \\
\hline SMA & 271 & $47 \%$ \\
SMK & 232 & $40 \%$ \\
\hline University & 76 & $13 \%$ \\
\hline & 579 & \\
\hline
\end{tabular}

The instrument used to collect data is an independent learning instrument developed by Hidayati and Listyani (2010). This instrument consists of 19 items that fall into 6 indicators. Using a Likert scale with five alternative answers, namely ( $5=$ strongly Agree/SS), (4 $=$ Agree $/ \mathrm{S}),(3=$ Neutral $/ \mathrm{N}),(2=$ Disagree/TS $)$, and $(1=$ Strongly Disagree /STS). The types of statements in this instrument are positive and negative statements.

Table 2 Instrument of Independent Learning

\begin{tabular}{|c|l|l|c|}
\hline No & \multicolumn{1}{|c|}{ Indicators } & $\begin{array}{c}\text { Number of } \\
\text { item }\end{array}$ & Total \\
\hline 1 & Indecency with others & $\begin{array}{l}1(1), 4(-), 6 \\
(+), 16(+)\end{array}$ & 4 \\
\hline 2 & Have a sense of confidence & $8(+), 10(-)$, & 3 \\
& & $17(+)$, & \\
\hline 3 & Dicipline & $11(+), 12$ & 3 \\
& & $(-), 18(+)$ & \\
\hline
\end{tabular}




\begin{tabular}{|c|l|l|c|}
\hline 4 & Have a sense of responsibility & $\begin{array}{l}7(+), 13(-), \\
14(+)\end{array}$ & 3 \\
\hline 5 & Have an Initiative & $\begin{array}{l}2(+), 3(+), \\
5(-)\end{array}$ & 3 \\
\hline 6 & Selfcontrol & $9(+), 15(-)$, & 3 \\
& & $19(+)$ & \\
\hline & & 19 \\
\hline
\end{tabular}

Before being used, the instrument was retested by calculating the test results item-total correlation, using the Pearson correlation formula Product Moment. The test results of the calculation show that the 19 statement items in the learning independence instrument are all valid. While the reliability test with Cronbach's Alpha score of 0.879 .

\section{RESULTS AND DISCUSSION}

Based on each statement in the questionnaire, all respondents showed independence in online learning as follows:

Table 3 The Result of the Questionnaire

\begin{tabular}{|c|l|c|c|c|}
\hline No & \multicolumn{1}{|c|}{ Indikator } & $\begin{array}{c}\text { Score } \\
\text { Average }\end{array}$ & $\begin{array}{c}\text { Deviation } \\
\text { Standar }\end{array}$ & Scale \\
\hline 1 & Indecency with others & 3.23 & 0.678 & $1-5$ \\
\hline 2 & $\begin{array}{l}\text { Have a sense of } \\
\text { confidence }\end{array}$ & 2.55 & 0.219 & $1-5$ \\
\hline 3 & Dicipline & 3.88 & 0.255 & $1-5$ \\
\hline 4 & $\begin{array}{l}\text { Have a sense of } \\
\text { responsibility }\end{array}$ & 1.94 & 0.163 & $1-5$ \\
\hline 5 & Have an Initiative & 2.32 & 0.120 & $1-5$ \\
\hline 6 & Self Control & 2.74 & 0.3111 & $1-5$ \\
\hline & \multicolumn{1}{|c|}{ TOTAL } & 2.78 & 0.289 & $1-5$ \\
\hline
\end{tabular}

Based on the tables above, it can be seen that the average score of learning independence for all participants is 2.78 , with St.Dev 0.289 on a scale of 1-5, it can be concluded that the level of independence of students for online learning tends to be low. If it is broken down by indicator, it can be seen that indicator 1, namely independence from others, has a mean score of 3.23 with St.Dev of 0.678 , on a scale of 5 , this result indicates that the level of independence from others in learning is rather high, because they are generally not too dependent. to the other party. For the second indicator: having selfconfidence, respondents are generally in the moderate stage with an average score of 2.55 and St.Dev 0.219 on a scale of 5 this score indicates a moderate position meaning they are confident enough to be able to learn online. The lowest average score in all indicators is the fourth indicator, which is having a sense of responsibility, the average score is 1.94 with St.Dev 0.163 . This shows that students generally do not have enough responsibility for the importance of learning during COVID 19, even though the score for the indicator of disciplined behavior is the highest, which is 3.88 , with St. Dev 0.255 . This score seems contradictory when in fact their disciplinary behavior is due to fear of not getting good results if they do not take part in online learning, not because of the responsibility to learn. This can be seen in the 5th indicator which shows that behaving based on self-initiative is still relatively low, because it only has an average score of 2.32, and the sixth indicator of self-control which also has a sufficient score of 2.74 .

The COVID-19 outbreak has forced learning activities to be carried out online. According to Purwanto, et al. (2020) all levels of education from elementary/ibtidaiyah schools to universities (universities) both under the Ministry of Education and Culture of the Republic of Indonesia and those under the Ministry of Religion of the Republic of Indonesia all have a negative impact because students, students and students are "forced" to study from home because face-to-face learning is abolished.

The results of the research above indicate that students have a rather low level of learning independence. The reason is that not all students, students and students are accustomed to learning through online [20]. In addition, many teachers and lecturers are still not proficient in teaching using internet technology or social media, especially in various regions, this could be one of the reasons for the low level of online learning. Students do not yet have a culture of distance learning because so far the learning system is implemented through face-toface, in Indonesia the use of e-learning is still slow, in contrast to developed countries outside which have used e-learning at a more advanced stage. According to [21]. Areas that do not have good internet network connectivity, online learning shows a different tendency, areas that are not covered by the internet network, one must go to certain areas.

The existence of Covid-19 forced students and students to study remotely using technology, this certainly brought a change from the usual face-to-face learning. Through face-to-face learning, students can meet directly with educators. Therefore, social interaction can still occur in the classroom where students still need guidance in learning. Through face-to-face learning, students can interact with educators and their friends so that students will directly get feedback from learning outcomes [22].

The positive side of online learning is growing independent learning learning without direct guidance from educators makes students independently seek 
information about the material and tasks given to them. This will require greater learner involvement to improve observational learning behavior. This behavior can be done by reading, interpreting discussion posts and discussing videos or learning content [23]. Through online learning, teenagers can freely set their own learning strategies, research conducted by Firman and Rahman (2020), shows that students are not pressured by time in online learning because they can set their own schedule and place where they want to attend lectures. Online learning allows access to information and knowledge at home and anywhere that is tailored to the convenience of students.

A limitation in this study is that respondents who were selected by snowball have a low level of representation, so generalizations cannot be made on the results. However, this study provides an overview of the conditions experienced by some students who take part in online learning.

\section{CONCLUSION}

The implementation of online learning that is implemented in educational practice as a result of the Covid-19 pandemic, it turns out that it cannot be carried out properly, because from the learner's perspective (students) do not yet have a high enough level of independence. This research shows that students still have enough confidence and responsibility to learn online. The habit of studying offline where students have direct contact makes them unable to be replaced online, because students must have their own readiness and selfdiscipline in carrying out learning.

\section{AUTHORS CONTRIBUTION}

Susan Fitriasari and Akhmad Fauzi conceived of the presented idea. All authors discussed the results and contributed to the final manuscript

\section{ACKNOWLEDGMENTS}

This research is a grant from the Indonesia University of Education. The authors would like to express sincere appreciation for all support provided.

\section{REFERENCES}

[1] Tahar, I., \& Enceng. (2006). Relationship of selfreliance learning and learning outcomes in distance education. Journal of Open and Distance Education, $7(2), 91-101$.

[2] Hapsari, A. S., Sismiati, A., \& Herdi. (2013). Profile adolescent independence (survey at Sma Negari 39 Jakarta students of class XI of the 2012/2013 school year). Insight: Journal of Guidance and Counseling, 2(1), 1-7. DOI: 10.21009/INSIGHT.021.01

[3] Hadi, S., \& Farida, F. (2012). Influence of interest Independence and learning resources towards pretense of learning students on subjects IPS class VII SMP Negeri 5 Ungaran. Journal Economic Education Dynamics Education, 7(1), 8-13. DOI: 10.15294/dp.v7i1.4913

[4] Pratiwi, I. D., \& Laksmiwati, H. (2016). Belief selfreliance and independence of learning in high school students State X. Journal of Theoretical and Applied $\begin{array}{llll}\text { Psychology, } & 7 & \text { (1), } & 43-49 .\end{array}$ 10.26740/jptt.v7n1.p43-49

[5] Huda, M. N., Mulyono, M., Rosyida, I., \& Wardono, W. (2019). Mobile-assisted learning independence learning. PRISMA: Proceedings of a national seminar Mathematics,798-806. Retrieved from https://

journal.unnes.ac.id/sju/index.php/prisma/article/vie $\mathrm{w} / 29270$

[6] Syartissaputri, N. P., Setiyowati, E., \& Siwabessy, L. (2014). Relationship between time management Independence of study of students of class X high school State 56 Jakarta. INSIGHT: Journal of Guidance and Counseling, 3(1), 88-94. DOI: 10.21009/ INSIGHT.031.15

[7] Astuti, E. P. (2016). Independence of learning mathematics junior high school students in Prembun district. Journal solar education education, 2(2), 6575. DOI: $10.37729 /$ jpse.v2i2.3464

[8] Al Fatihah, M. (2016). The Relationship Between Independence Learn with PAI Student Learning Achievement Class Students III SDN Panularan Surakarta, At-Tarbawi, 1, (2), 197-208. DOI: 10.22515/attarbawi.v1i2.200

[9] Syartissaputri, N. P., Setiyowati, E., \& Siwabessy, L. (2014). Relationship between time management Independence of study of students of class X high school State 56 Jakarta. INSIGHT: Journal of Guidance and Counseling, 3(1), 88-94. DOI: 10.21009/ INSIGHT.031.15

[10] Sundayana, R. (2016). The relationship between learning styles, Independence of learning, and ability Problem solving of junior high school students in lessons mathematics. Stkip journal of mathematics education Garut, 5(2), 75-84. DOI: 10.31980/mosharafav5i2.262

[11] Merdinger, Joan, M., Hines, A.M., Osterling, K.L., \& Wyatt, P. (2005). Patgways to college for former foster youth: Understanding factos that contribute to educational success. Child Welfare League of America, LXXXIV, 867-898.

[12] Woolfolk. (2008). Educational Psychology. Active Learning Edition Tenth Edition. Boston: Allyn \& Bacon.

[13] Zimmerman, B.J., \& Martinez-Pons, M. (2001). Students differences in self regulated learning: Relating grade, sex, and giftedness to self efficacy and strategy use. Journal of Educational Psychology, 82 (1), 51-59. 
[14] Baumert et al., (2002). Self Regulated Learning as Cross Cultural Concept. Diakses dari http://www.mpibberlin.mpg.de/pisa/pdfs/ccengl.pdf.

[15] Sungur, S. and Tekkaya, C. (2006). Effects of problembased learning and traditional instruction on self - regulated learning. The Journal of Educational $\quad$ Research 99.5. (http://find.galegroup.com/gps/retrieve.do?contentS $\underline{\text { et }=I A C D o c u m e n t s \& r e s u l t L i s t T y p e}=$ RESULT_LIS T\&qry

[16]Zimmerman, B. J. 1989. A Social Cognitive View of Self-Regulated Academic Learning. Journal of Educational Psychology. No.81, hal 329-339.

[17] Woolfolk. (2008). Educational Psychology. Active Learning Edition Tenth Edition. Boston: Allyn \& Bacon.

[18] Alexander. (2006). Psychology in Learning and Instruction. Upper Saddle River. N.J: Merrill/Prentice Hall.

[19] Pressley, M. (1995). More about the development of self regulation complex, long term, and throughly social. Educational Psychologist, 30,
207-212.

[20] Purwanto, A., Pramono, R., Asbari, M., Hyun, C., Wijayanti, L., Putri, R., \& santoso, priyono. (2020). Exploratory Study of Pandemic Impacts COVID-19 to the learning process Online in elementary school. EduPsyCouns: Journal of Education, Psychology and Counseling, 2(1), 1-12. Retrieved from https://ummaspul.e-journal. $\mathrm{id} /$ Edupsycouns/article/view/397

[21] Firman, \& Rahman, S. R. (2020). Online Learning In the midst of the Covid-19 pandemic. Indonesian Journal of Educational Science (IJES), 2(2), 81-89. DOI: $10.31605 /$ ijes.v2i2.659

[22] Anhusadar, L. O. (2020). Persepsi Mahasiswa PIAUD terhadap Kuliah Online di Masa Pandemi. KINDERGARTEN: Journal of Islamic Early Childhood Education, 3 (1), 44-58. DOI: 10.24014/ kjiece.v3i1.9609

[23] Herliandry, L. D., Nurhasanah, Suban, M. E., \& Kuswanto, H. (2020). Learning in Time Pandemic Covid-19. Journal of Educational Technology, 22(1), 65-70. DOI: $10.21009 /$ jtp.v22i1.15286 